\title{
INFLUENCE OF SUPERPLASTICIZER AND VARYING AGGREGATE SIZE ON THE DRYING SHRINKAGE AND COMPRESSIVE STRENGTH OF LATERISED CONCRETE
}

\author{
F. Falade ${ }^{1,}$, B. Ukponu ${ }^{2}$ and O. J. Ugbaja ${ }^{3}$ \\ 1,2,3 DePARTMENT OF CiVIL AND ENVIRONMENTAL ENGINEERING, UNIVERSITY OF LAGOS, AKOKA, LAGOS, NIGERIA \\ E-mail addresses.1 ffalade@unilag.edu.ng,2beu2ng@gmail.com,33ugbajajulio2@gmail.com
}

\begin{abstract}
This paper presents the results of the study on the influence of superplasticizer and varying aggregate size on the drying shrinkage and compressive strength of laterised concrete. Four different samples of laterised concrete were made from prescribed mix ratio of 1:1:2 which include; two control specimens made with different coarse aggregate sizes (12.5mm and $19 \mathrm{~mm}$ ) and another two specimens that have the same composition as the control samples with addition of superplasticizer (Conplast 430). The compressive strength and drying shrinkage were determined at the curing periods (7, 14, 21 and 28 days). The results showed that specimens made with $12.5 \mathrm{~mm}$ diameter coarse aggregate and superplasticizer developed a maximum compressive strength $\left(44 \mathrm{~N} / \mathrm{mm}^{2}\right)$ at $28^{\text {th }}$ day. This maximum compressive strength was $29.6 \%, 31.8 \%$ and $4.6 \%$ greater than the compressive strength developed by the control specimens and specimens made with $19 \mathrm{~mm}$ diameter coarse aggregate and superplasticizer. Specimens made with $19 \mathrm{~mm}$ diameter coarse aggregate and superplasticizer developed the minimum shrinkage strain $\left(1.48 \times 0^{-3}\right)$ at $90^{\text {th }}$ day. This value was $17 \%, 13.5 \%$ and $8.1 \%$ less than shrinkage strain of the control specimens and specimen made with 12.5mm coarse aggregate size and superplasticizer. The addition of superplasticizer increased the compressive strength and reduced the shrinkage strain of all specimens; while increase in coarse aggregate size reduced both compressive strength and drying shrinkage.
\end{abstract}

Keywords: Coarse aggregate size, Compressive strength, Drying shrinkage, Laterised concrete and Superplasticizer

\section{INTRODUCTION}

Concrete is the most used construction material around the world due to its ease of application, high compressive strength, high stiffness, durability, relatively low cost, and its ability to be formed into any shape. However, concrete like any other solid porous material goes through volume reduction (shrinkage) when it changes from plastic to hardened phase. Concrete shrinkage is one of the major sources of cracking that limits the serviceability and durability of concrete. The various types of shrinkage that affect concrete are drying, plastic, autogenous, chemical, carbonation and thermal shrinkage. Change in concrete occurs as a result of drying, self-desiccation, chemical reactions and temperature changes. Coarse aggregate restrains shrinkage action and induces tensile stress in concrete which produces cracks if in excess of the tensile strength. Tensile cracks in the concrete structure reduce the structural properties.

Several works have been carried out on the shrinkage and compressive strength of concrete. Holt [1] investigated early age autogenous shrinkage of concrete made with superplasticizer and different types of cement. The results showed that three major factors: hydration process, amount of bleeding and setting times contribute to autogenous shrinkage. Arthur, et al. [2] reported the effect of water content on drying shrinkage of concrete. They found that increasing the amount of water would increase the drying shrinkage, and the values of final shrinkage for ordinary concrete were between $4 \times 10^{-4}$ and $8 \times 10^{-4}$, depending on the initial water content, ambient temperature, humidity and the nature of aggregate. Neville [3] investigated the influence of aggregate content in concrete on the ratio of the shrinkage of concrete to the shrinkage of neat cement paste. The results showed that shrinkage value decreased with increase in amount of aggregate; for example, increasing the aggregate content from 71 to 74 per cent resulted in a 20 per cent reduction in shrinkage. He concluded that increase in aggregate content could be achieved through the use of larger coarse aggregate size and chemical admixtures. Ahmad, et al. [4] investigated the effect of super-plasticizers: Rheobuild 1100 and Rheobuild $561 \mathrm{M}$ on the workability of concrete;

* Corresponding author, tel: + 234-909-258-6020 
percentage of water reduction and quantity of cement savings made. They found that the addition of the superplasticizers $(0.8 \%$ weight of cement) reduced quantity of water required to produce grade $25 \mathrm{~N} / \mathrm{mm}^{2}$ concrete. They concluded that both samples of super-plasticizer improved the properties of concrete investigated; however, concrete samples that contained Rheobuild $561 \mathrm{M}$ showed superior performance in all the properties investigated. Raheem, et al. [5] studied the effects of admixtures on the properties of Corn Cob Ash-cement concrete. The properties examined were workability and compressive strength of the concrete. Three different types of admixtures were used. These admixtures include: accelerant, plasticizer and retarder. From the results obtained, it was concluded that all the admixtures improved the workability of corn cob ash cement concrete as well as increased the compressive strength at all ages. Also, results from samples showed that samples containing plasticizers exhibited higher workability and strength at both early and later curing ages. Alsadey [6] investigated the influence of super-plasticizer (sikament ${ }^{\circledR}$ R2002) on the strength of concrete. The variable in that investigation was varying doses of the super-plasticizer applied into the concrete mix. The results of the investigation showed that the admixture improved the workability and the compressive strength of the concrete. Ikponmwosa and Salau [7] found that laterite could be used as partial replacement of dredged sand in normal weight concrete production. This conclusion was based on findings that laterite improved particle size distribution of the dredged sand; consequently, reduced the porosity and increased the compressive strength of concrete. Falade, et al. [8] investigated the potential of laterite as replacement of dredged sand in foamed concrete production. The results showed that increase in proportions of laterite reduced the spreadability and increased the compressive strength of self-compacting concrete. They found that 20 per cent laterite was the maximum replacement of dredged sand that satisfied the workability criterion. Ikponmwosa and Falade [8] reported that the strength properties of fibrereinforced laterised concrete under normal laboratory temperature showed consistent trend of increase in strength with age. They also reported that 25 per cent laterite as partial replacement of dredged sand was the maximum that satisfied the workability requirement and increased the compressive strength. Osunade [10] reported that laterite is a type of fine aggregate which consists of clayey iron, aluminium oxides and hydroxides. His findings showed that laterite is readily available adjacent to project sites and cheap to procure in all parts of Nigeria. The research findings presented show that laterite, superplasticizer and increase in coarse aggregate size could be used to reduce the evaporable water in concrete which causes shrinkage and reduction in structural properties of concrete.

The objectives of this investigation are to examine the influence of plasticizers and varying the aggregate size on the drying shrinkage and compressive strength of laterised concrete.

\section{MATERIALS AND METHODOLOGY}

\subsection{Materials}

The coarse aggregate used was crushed rock with rough surface texture and angular shape. It was obtained from Oriental - FEMAB Quarry, Ibadan, Oyo State, Nigeria.The fine aggregates used were river sand and laterite obtained from a borrow pit at Ibafo, Ogun State. The coordinates of the borrow pit are $6.8 .76^{\circ} \mathrm{N}$ and $3.3357^{\circ} \mathrm{E}$. The particle size distribution of the fine and coarse aggregates were determined in accordance with BS EN 12620 [11]. Single size coarse aggregates of $12.5 \mathrm{~mm}$ and $19 \mathrm{~mm}$ were used for the experiment. Additional properties of coarse and fine aggregates which were determined include specific gravity, aggregate crushing and impart values, moisture content and Atterberg limits.

\subsection{Experiment}

The batching of the concrete constituent materials (cement, fine aggregate, coarse aggregate and water) was done by weighing based on prescribed mix ratio of 1:1:2. The fine aggregate portion consists of $25 \%$ and $75 \%$ laterite and river sand respectively. Four different samples (Table 1) were made with different materials composition. $150 \mathrm{~mm}$ cubes and short columns $(100 \mathrm{~mm} \times 100 \mathrm{~mm} \times 500 \mathrm{~mm})$ made from the different samples were used to measure the compressive strengths and shrinkage values at the testing ages. The $150 \mathrm{~mm}$ cubes were cured in water for the curing periods (7, 14, 21 and 28 days) before they were tested in a compression machine in accordance with BS EN 12390-3 [12]. The short columns were demoulded after $24 \pm 1 / 2$ hours and cured in water for 7 days; they were then hung on a shrinkage test rig. Plate 1 shows the experimental set up for the shrinkage test. It consists of a simple steel frame with an adjustable height beam, measuring gauge which is calibrated to read to the nearest $0.01 \mathrm{~mm}$. The values of the shrinkage deformation were recorded daily for a period of 90 days.

\section{RESULTS AND DISCUSSION}

The results of this investigation are presented under the following headings: coarse and fine aggregates properties, shrinkage and compressive strength properties. 


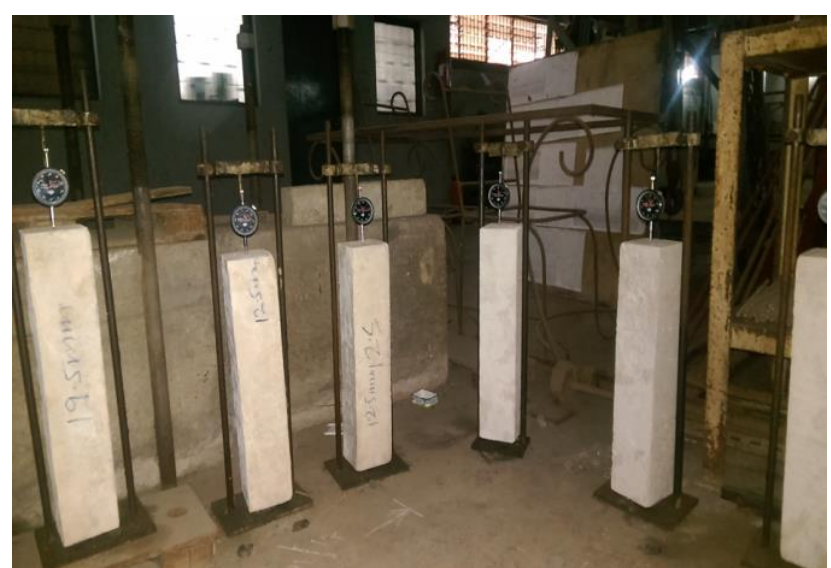

Plate 1: Laboratory setup for measuring shrinkage strain in the specimens

Table 1: Materials composition for different samples of concrete

\begin{tabular}{|c|c|}
\hline Sample & Materials Composition \\
\hline A & $\begin{array}{l}\text { Ordinary Portland Cement, Laterite (25\%), River } \\
\text { sand }(75 \%) \text {, Granite }(12.5 \mathrm{~mm}) \text { and } \mathrm{w} / \mathrm{c}-0.55\end{array}$ \\
\hline B & $\begin{array}{l}\text { Ordinary Portland Cement, Laterite( } 25 \%) \text {, River } \\
\text { sand }(75 \%) \text {, Granite }(12.5 \mathrm{~mm}), \mathrm{w} / \mathrm{c}-0.4 \text { and } \\
\text { Conplast SP430 ( } 500 \mathrm{ml} \text { per } 100 \mathrm{~kg} \text { of cement })\end{array}$ \\
\hline $\mathrm{C}$ & $\begin{array}{l}\text { Ordinary Portland Cement, Laterite (25\%), River } \\
\text { sand }(75 \%) \text {, Granite }(19 \mathrm{~mm}) \text { and } \mathrm{w} / \mathrm{c}-0.55\end{array}$ \\
\hline $\mathrm{D}$ & $\begin{array}{l}\text { Ordinary Portland Cement, Laterite ( } 25 \%) \text {, River } \\
\text { sand }(75 \%), \text { Granite }(19 \mathrm{~mm}), \mathrm{w} / \mathrm{c}-0.4 \text { and } \\
\text { Conplast SP } 430(500 \mathrm{ml} \text { per } 100 \mathrm{~kg} \text { of cement })\end{array}$ \\
\hline
\end{tabular}

\subsection{Properties of constituents Aggregate}

Figure 1shows the particle size distribution curves of the granite, river sand and laterite. The laterite contains 5 , 60 and $25 \%$ gravel, sand and fines particles; the river sand contains 5, 93 and $2 \%$ gravel, sand and fines. The particle sizes of the granite are distributed between fine and medium gravel. The particle size distribution of the aggregates shows that the combination of those aggregates would result in aggregate mixture with improved grading. Other properties of both fine and coarse aggregate examined: specific gravity, crushing and impact values, moisture content and the Atterrberg limits are presented in Table 2.

\subsection{Workability of Concrete}

Table 3 shows the degree of workability of the four different samples of concrete (A, B, C and D) made with different coarse aggregate sizes and superplasticizer. Increase in coarse aggregate size. Water/cement ratio and addition of superplasticizer increased the workability of laterised concrete from medium to very high. These observations can be attributed to reduction in surface area of aggregate in concrete and ability of superplasticizer to deflocculate the fines (cement and sand matrix) in concrete to reduce the amount of water required for mixing.

Table 2: Physical Properties of Coarse and Fine Aggregates

\begin{tabular}{llll}
\hline Physical Property & Sand & Laterite & Granite \\
\hline Specific density & 2.66 & 2.61 & 2.71 \\
$\begin{array}{l}\text { Moisture content } \\
(\%)\end{array}$ & 1.3 & 5.2 & - \\
$\begin{array}{l}\text { Crushing value } \\
(\%)\end{array}$ & - & - & 16.53 \\
$\begin{array}{l}\text { Impact value (\%) } \\
\text { Optimum }\end{array}$ & - & - & 6.97 \\
moisture content & - & 7.2 & - \\
$(\%)$ & & & \\
Liquid limit (\%) & - & 47 & - \\
Plastic limit (\%) & - & 25 & - \\
Plastic index (\%) & - & 22 & - \\
\hline
\end{tabular}

Table 3: Degree of Workability of the Different Samples

\begin{tabular}{llll}
\hline $\begin{array}{l}\text { Coarse } \\
\text { aggregate Size } \\
(\mathrm{mm})\end{array}$ & $\begin{array}{l}\text { Slump } \\
\text { Value } \\
(\mathrm{mm})\end{array}$ & $\begin{array}{l}\text { Type of } \\
\text { Slump }\end{array}$ & $\begin{array}{l}\text { Degree of } \\
\text { workability }\end{array}$ \\
\hline $12.5(\mathrm{~A})$ & 80 & $\begin{array}{l}\text { True } \\
\text { slump }\end{array}$ & Medium \\
$\begin{array}{l}12.5(\text { Conplast } \\
\text { SP 430) (B) }\end{array}$ & 180 & $\begin{array}{l}\text { Collapse } \\
\text { True }\end{array}$ & Very High \\
$\begin{array}{l}19(\mathrm{C}) \\
\begin{array}{l}19(\text { Conplast SP } \\
\text { 430) (D) }\end{array}\end{array}$ & 105 & $\begin{array}{l}\text { slump } \\
\text { Collapse }\end{array}$ & Very High \\
\hline
\end{tabular}

3.3 Effect of superplasticizer on drying shrinkage of laterized concrete

Figure 2 shows the variation of shrinkage strain of the four different samples of concrete with age. The shrinkage strain of all the samples increased with age and attained maximum values after 70 days. For example the shrinkage strains of sample A at 8, 36, 54, 75 and 90 days were $650,1400,1750,1800$ and $1800 \times 10^{-6}$ respectively. The addition of superplasticizer (Conplast SP430) in laterized concrete reduced the drying shrinkage strain by $10.3 \%$ and $5.7 \%$ for sample with $12.5 \mathrm{~mm}$ and $19 \mathrm{~mm}$ coarse aggregate sizes; while increase in the size of coarse aggregate reduced drying shrinkage by $14.8 \%$. For example, the shrinkage strains of samples A (12.5mm), B (12.5mm + Conplast SP430), C $(19 \mathrm{~mm})$ and D $\left(19 \mathrm{~mm}+\right.$ Conplast SP430) at $90^{\text {th }}$ day were $1850,1700,1600$ and $1500 \times 10^{-6}$.This observation can be attributed to two factors, which are increased shrinkage restrain and reduction in evaporable water. 


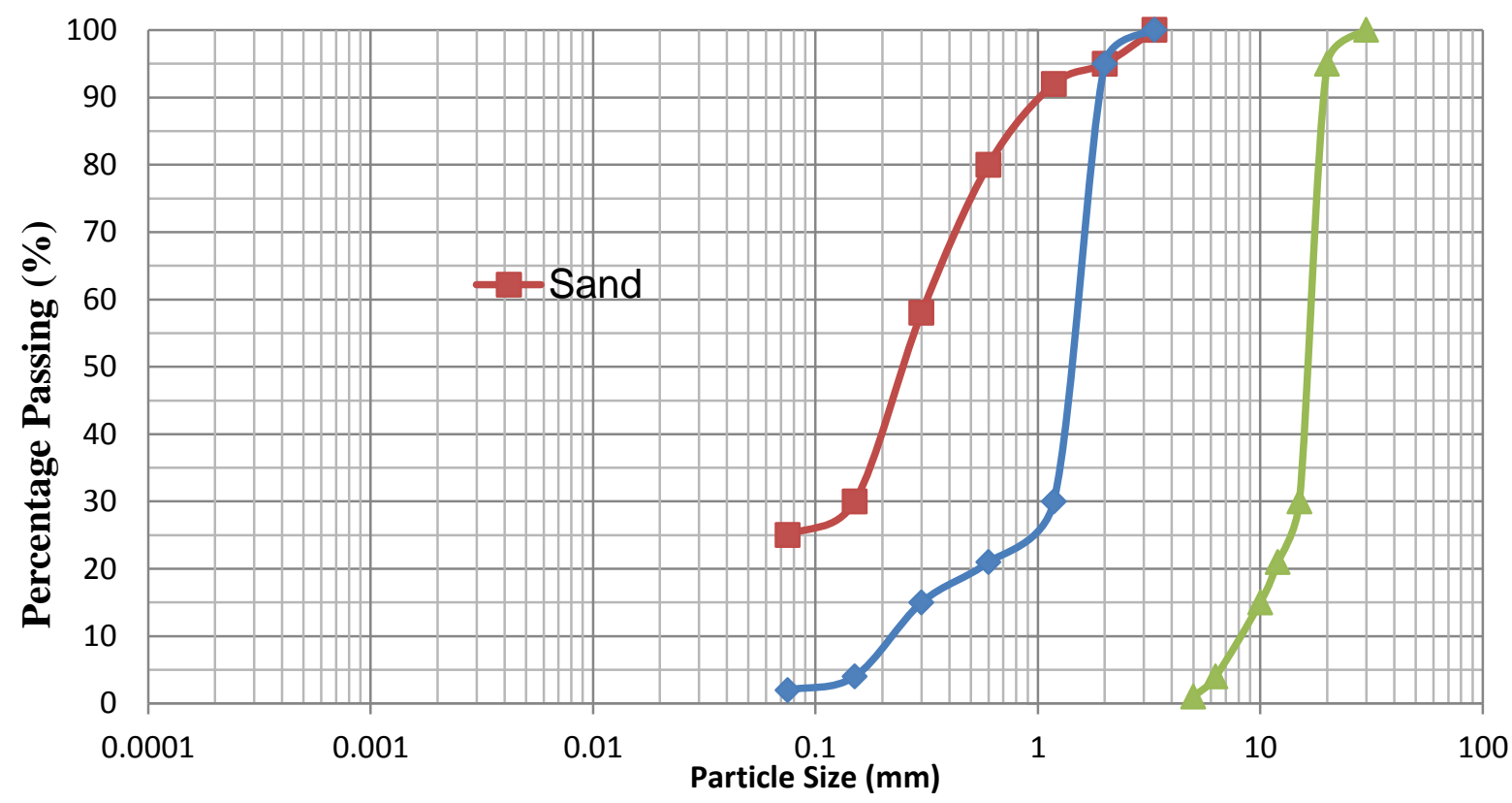

\begin{tabular}{|l|c|c|c|c|c|c|c|c|c|}
\hline \multirow{2}{*}{ CLAY } & Fine & Medium & Coarse & Fine & Medium & Coarse & Fine & Medium & Coarse \\
\cline { 2 - 7 } & \multicolumn{3}{|c|}{ SILT } & \multicolumn{4}{|c|}{ SAND } & \multicolumn{3}{c|}{ GRAVEL } \\
\hline
\end{tabular}

Fig 1: Coarse and fine aggregates particle size distribution

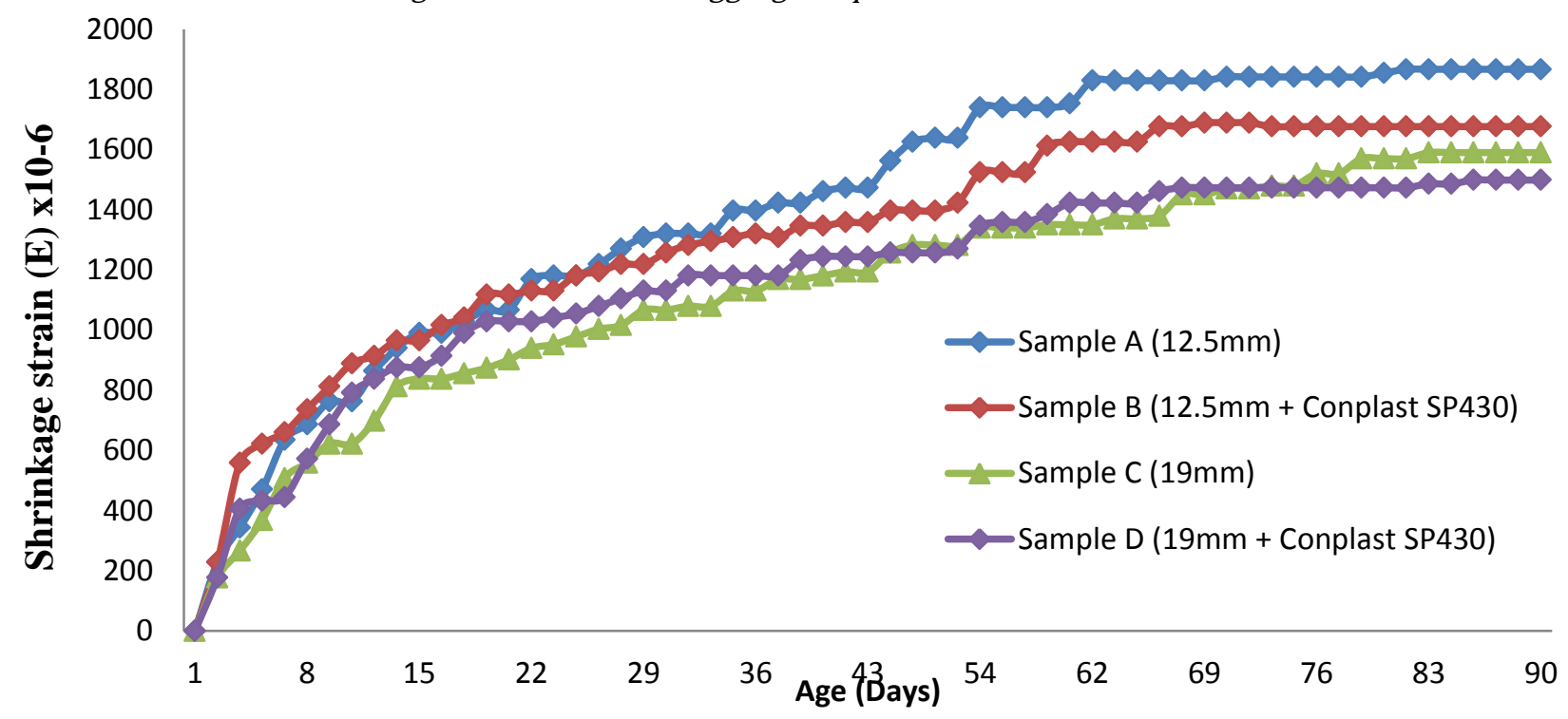

Figure 2: Variation of shrinkage strains of the four Different Samples of Concrete with Age.

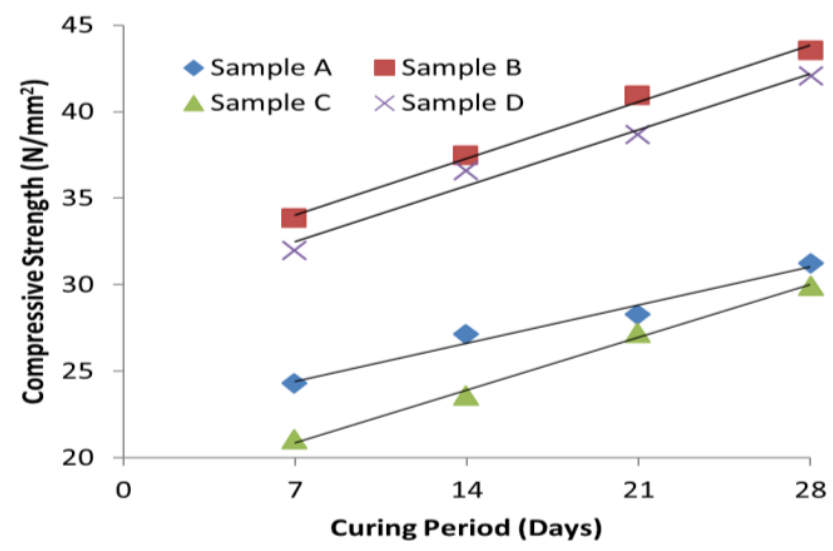

Figure 3: Variation of compressive strength with curing period of the four samples of concrete

\subsection{Compressive strength.}

Figure 3 shows the variation of compressive strength with curing period for the four different samples of concrete. The compressive strength of all the specimens increased with increase in curing periods. For example, the compressive strength of Samples A and B at 7, 14, 21 and 28 days were $24.3 \mathrm{~N} / \mathrm{mm}^{2}, 27.1 \mathrm{~N} / \mathrm{mm}^{2}, 28.3 \mathrm{~N} / \mathrm{mm}^{2}$ and $31.26 \mathrm{~N} / \mathrm{mm}^{2} ; \quad 33.78 \mathrm{~N} / \mathrm{mm}^{2}, \quad 36.59 \mathrm{~N} / \mathrm{mm}^{2}$, $40.89 \mathrm{~N} / \mathrm{mm}^{2}$ and $43.56 \mathrm{~N} / \mathrm{mm}^{2}$. Also, increase in coarse aggregate size reduced the compressive strength developed at all testing ages. For example, Sample A with coarse aggregate size of $12.5 \mathrm{~mm}^{2}$ compressive strength at 7, 14, 21 and 28 days were $24.3 \mathrm{~N} / \mathrm{mm}^{2}, 27.1 \mathrm{~N} / \mathrm{mm}^{2}$, 
$28.3 \mathrm{~N} / \mathrm{mm}^{2}$ and $31.26 \mathrm{~N} / \mathrm{mm}^{2}$ respectively, while the equivalent values of Sample C with coarse aggregate size of $19 \mathrm{~mm}^{2}$ were $21.04 \mathrm{~N} / \mathrm{mm}^{2}, \quad 23.56 \mathrm{~N} / \mathrm{mm}^{2}$, $27.26 \mathrm{~N} / \mathrm{mm}^{2}$ and $29.93 \mathrm{~N} / \mathrm{mm}^{2}$ respectively. Comparing the compressive strength of $\mathrm{A}$ with $\mathrm{B}$ and $\mathrm{C}$ with $\mathrm{D}$, showed that the addition of superplasticizer increased the compressive strength by $39.35 \%$ and $40.56 \%$ respectively. These observations can be attributed to the amount of voids in the concrete due to materials composition. Increase in coarse and fine aggregates sizes increase the inter-particle voids in the aggregate and ultimately, in the concrete. The application of superplasticizer reduces the amount of water required for production of concrete which reduces the evaporable water in concrete mix and the voids it creates. These results support the research findings of Neville(13); Gambhir (14) that compressive strength of concrete is dependent on the volume of voids in the internal structure.

\section{CONCLUSION}

From the foregoing, the following conclusions are made:

1) The shrinkage strain of laterised concrete increased with time and attained maximum value after 70 days.

2) Increase in the size of coarse aggregate in the laterised concrete from $12 . \mathrm{mm}$ to $19 \mathrm{~mm}$ reduced the shrinkage strain by $14.8 \%$.

3) The addition of superplasticizer (Conplast SP430) in the production of laterised concrete made with $12.5 \mathrm{~mm}$ and $19 \mathrm{~mm}$ coarse aggregate sizes reduced the shrinkage strain by 10.3 and $5.7 \%$ respectively.

4) The combined effects of increase in coarse aggregate size and addition of superplasticizer resulted in the reduction ofshrinkage strain by $19.72 \%$ for Sample Dcompared with Sample A.s

5) The laterised concrete made with superplasticizer has a higher compressive strength than conventional laterised concrete irrespective of the size of coarse aggregate.

6) The compressive strength of laterised concrete decreased with increase in coarse aggregate size.

\section{REFERENCES}

[1] Holt, E.E Early Age Autogenous Shrinkage of Concrete. Publication of Technical Research Centre of Finland 446: pp184. Retrieved from http://www.vtt.fi/inf/pdf/ publications/2001/P446.pdf 2001

[2] Arthur, H.N., David, D., Charles, W.D. (2010). Design of Concrete Structures 14th Edition, NY, McGrawHill.
[3] Neville, A.M.. Properties of Concrete, $4^{\text {th }}$ Edition, NY: John Wiley \& Sons,Inc. 1996

[4] Ahmad, S., Nawaz, M., Elahi, A. Effect of Superplasticizers on Workability and Strength of Concrete. Proceedings of $30^{\text {th }}$ Conference on our World in Concrete \& Structures, Singapore: 23-24 2005

[5] Raheem, A.A., Oyebisi, S. O., Akintayo, S. O., Oyeniran, M. I. . Effects ofAdmixtures on the Properties of Corn Cob Ash Cement Concrete. Leonardo Electronic Journal of Practices and Technologies, 1583-1078:13-20, 2010

[6] Alsadey, S. Influence of Superplasticizers on Strength of Concrete. Journal of Research in Engineering and Technology, 2277-4378:(1):3 British Standards Institution, London. 2012.

[7] Ikponmwosa. E.E. and Salau, M. Effect of Heat on Laterized Concrete. MaejoInternational Journal of Science and Technology, 4(1):33-44, 2010.

[8] Falade, F., Ikponmwosa, E.E.,Ukponu, B. E.(2013). The Potential of Laterite as Fine Aggregate in Foamed Concrete Production. Journal of International Institute for Science Technology \& Education, 3(10):46-54.

[9] Ikponmwosa, E.E. and Falade, F. A Study of the Properties of Fibre- ReinforcedLaterized Concrete. Journal of Raw Material Research, 3:46-55. 2006.

[10] Osunade, J.A. . Effect of Replacement of Laterite Soils with Granite Fines on the Compressive Strength and Tensile of Laterized Concrete, Building and Environment, 37(4):491-496. 2002.

[11] BS EN 12620 Testing for geometrical properties of aggregate; determination of particle size distribution - sieving method. 2013

[12] BS EN 12390 -3 . Testing harden concrete; compressive strength of test specimens, 2009.

[13] Neville, A. M. Properties of Concrete, $4^{\text {th }}$ Edition, Edinburgh Gate, United Kingdom: Pearson Education Limited. 2003.

[14] Gambhir, M. L. . Concrete Technology: Theory and Practice $5^{\text {th }}$ Edition. New Delhi, India. McGraw-Hill. 2013.

[15] BS EN 12350-2. Method for Determination of slump. 2000

[16] Falade, F., Ikponmwosa, E. E.,Ukponu, B. E.. The Potential of Laterite as Fine Aggregate in Foamed Concrete Production. Journal of International Institute for Science Technology \& Education, 3(10):46-54. 2013

[17] Osunade, J. A.. Effect of Replacement of Laterite Soils with Granite Fines on the Compressive Strength and Tensile of Laterized Concrete, Building and Environment, 37(4):491-496, 2002 
[18] Gambhir, M. L.. Concrete Technology: Theory and Practice $5^{\text {th }}$ Edition. New DelhiIndia. McGraw-Hill. 2013.

[19] Holt, E.E.. Early Age Autogenous Shrinkage of Concrete. Publication of Technical Research Centre of Finland 446: pp184. Retrieved from http://www.vtt.fi/inf/pdf/publications/2001/ P446.pdf 2001.

[20] Ikponmwosa, E.E. and Falade, F.. A Study of the Properties of Fibre- ReinforcedLaterized Concrete. Journal of Raw Material Research, 3:46-55. 2006

[21] Ikponmwosa. E. E. and Salau, M. Effect of Heat on Laterized Concrete. Maejo International Journal of Science and Technology, 4(1):33-44. 2010.
[22] Neville, A. M. . Properties of Concrete, $4^{\text {th }}$ Edition, NY: John Wiley \& Sons,Inc. 1996.

[23] Osunade, J. A. Effect of Replacement of Laterite Soils with Granite Fines on the Compressive Strength and Tensile of Laterized Concrete, Building and Environment, 37(4):491-496: Pearson Education Limited. 2002.

[24] Raheem, A. A., Oyebisi, S. O., Akintayo, S. O., Oyeniran, M. I. Effects of Admixtures on the Properties of Corn Cob Ash Cement Concrete. Leonardo Electronic Journal of Practices and Technologies, 1583-1078:13-20, 2010. 